\title{
Gebel Ramlah—a Unique Newborns' Cemetery of the Neolithic Sahara
}

\author{
Agnieszka Czekaj-Zastawny • Tomasz Goslar • \\ Joel D. Irish • Jacek Kabaciński (i)
}

Published online: 20 July 2018

(C) The Author(s) 2018

\begin{abstract}
Post-Pleistocene climatic improvement in the Northern Hemisphere after ca. 9550 BC allowed human populations to recolonize large parts of North Africa in what is today the Sahara Desert. In the Egyptian Western Desert, the beginnings of human occupation date as early as ca. 9300 BC. Occupation continued until the middle of the third millennium $\mathrm{BC}$ when final desertification of the area no longer afforded human occupation. The settlement of the Neolithic cattle and sheep/goat herders developed along with the rhythm of alternating wet and dry climatic
\end{abstract}

Electronic supplementary material The online version of this article (https://doi.org/10.1007/s10437-018-9307-1) contains supplementary material, which is available to authorized users.

A. Czekaj-Zastawny

Institute of Archaeology, Polish Academy of Sciences, ul.

Sławkowska 17, 31-016 Kraków, Poland

T. Goslar

Faculty of Physics, Adam Mickiewicz University, ul. Umultowska 85, 61-614 Poznań, Poland

T. Goslar

Poznań Radiocarbon Laboratory, Foundation of the A.

Mickiewicz University, ul. Rubież 46, 61-612 Poznań, Poland

J. D. Irish

Research Centre in Evolutionary Anthropology and Palaeoecology, School of Natural Sciences and Psychology, Liverpool John Moores University, Byrom Street, Liverpool L3 3AF, UK

J. Kabaciński $(\square)$

Institute of Archaeology and Ethnology, Polish Academy of Sciences, ul. Rubież 46, 61-612 Poznań, Poland e-mail: jacek.kabacinski@ interia.pl oscillations. One of the areas occupied intensively during the early and middle Holocene was Gebel Ramlah. Pastoral populations established their settlements around the shores of a paleo-lake adjacent to a rocky massif, to exploit the local savannah environment. During most of the Neolithic, they buried their dead dispersed outside of their settlements. Only during the Final Neolithic (after ca. $4600 \mathrm{BC}$ ) did they place them exclusively in cemeteries. Of six Final Neolithic cemeteries investigated at Gebel Ramlah to date, one is entirely unprecedented, not only in North Africa but also globally at such an early date. For just under 200 years (ca. 4500-4300 BC), it served exclusively for the inhumation of infants who died around (perinate) or shortly after the time of birth (neonate). Thirty-two burial pits contained skeletal remains of 39 individuals, not only infants but also at least two adult females accompanied by perinates/neonates. Older children ( $>3$ years) were interred at a nearby cemetery that primarily comprised adults.

Résumé L'amélioration climatique post-pléistocène postérieure à ca. $9550 \mathrm{cal}$. $\mathrm{BC}$ a permis aux populations humaines de recoloniser d'importants espaces en Afrique du Nord, localisés dans ce qui est. aujourd'hui le désert du Sahara. Dans le désert occidental Egyptien, les débuts de l'occupation humaine sont datés d'environ $9300 \mathrm{cal}$. BC. Cette dernière se poursuit jusqu'à la première moitié du $3^{\mathrm{e}}$ millénaire $\mathrm{BC}$, lorsque l'aridification du milieu est telle qu'elle ne permet plus aux hommes de continuer à habiter la région. Les installations des pasteurs-éleveurs néolithiques se développent en fonction des rythmes d'alternance des oscillations climatiques humides et sèches. 
Gebel Ramlah est une de ces zones densément peuplées au cours de l'Holocène ancien et moyen. Les populations pastorales s'établirent autour des rives d'un paléolac adjacent à un massif rocheux afin d'exploiter la savane environnante. Au cours de la majeure partie du Néolithique, les morts sont enterrés de manière éparse, à l'extérieur des agglomérations. Ce n'est qu'à partir du néolithique final (après 4600 cal. BC) que les inhumations ont lieu exclusivement au sein des nécropoles. Une des six nécropoles du Néolithique final fouillées à ce jourà Gebel Ramlah a livré des vestiges sans précédent en Afrique du Nord et ailleurs pour une date si ancienne. Pendant un peu moins de 200 ans, cette nécropole a servi exclusivement à l'inhumation d'immatures morts en période péri- ou néonatale. Trente-deux fosses à inhumation contenaient les parties squelettiques de trente-neuf individus, majoritairement des immatures, mais aussi au moins deux femmes adultes accompagnées d'enfants d'âge péri- et/ou néonatal. Les enfants plus âgés (de plus de trois ans) étaient inhumés dans une nécropole proche composée majoritairement d'adultes.

Keywords Neonates' cemetery - Pastoral society Neolithic $\cdot$ Northeast Africa $\cdot$ Sahara

\section{Introduction}

Today, the Sahara is the largest hyper-arid desert area in the world, covering over $9,000,000 \mathrm{~km}^{2}$ of North Africa. However, during the last 12,000 years, environmental conditions varied. Along with fast and radical climatic changes in the Northern Hemisphere at the end of the Late Glacial and beginning of the Holocene, ca. 9550 BC (Alley et al. 1993; Lowe et al. 2008), the first signs of climatic improvement are readable in the early Preboreal period of the Sahara (Kuper and Kropelin 2006). In the Egyptian Western Desert, part of the Eastern Sahara, the advent of the first humid interphase is dated to ca. $9300 \mathrm{BC}$ and correlates with the first appearance of Neolithic humans there (Schild and Wendorf 2013). Neolithic pastoralists were then continuously present in this area for almost 6000 years, not departing until the middle of the third millennium BC (Applegate and Zedeño 2001).

The Western Desert of Egypt has been intensively studied by the Combined Prehistoric Expedition (CPE) since the early 1970s, when it relocated fieldwork from the Nile Valley after the Nubian Campaign (Wendorf 1968; Wendorf et al. 1976; Schild and Wendorf 2002). Research concentrated on the recognition of settlements along the shores of temporary paleo-lakes (or playa) of the NabtaKiseiba region, within frameworks of chronostratigraphic units and correlated with major climatic fluctuations. Four occupation periods were defined: Early (ca. 93006150 BC), Middle (ca. 6050-5550 BC), Late (ca. 55004650 BC), and Final Neolithic (ca. 4600-3600 BC), each separated by dry periods manifested by remarkable eolian sedimentation and erosion. Each wet period was different in terms of rainfall amount, temperature, and species of fauna and flora present. Consequently, there were different cultural adaptations to each environment, including lifestyle and social organization (Wendorf and Schild 2001a, b; Schild and Wendorf 2013). In 2001, some CPE research activity was moved to the Gebel Ramlah area, ca. $150 \mathrm{~km}$ west of Abu Simbel (Fig. 1), to investigate what are now known as the first Neolithic cemeteries of the Egyptian Western Desert, dated to ca. 4500-4300 BC (sites E-01-2, E-03-1, and E-03-2) (Kobusiewicz et al. 2004, 2010).

In 2009, a few hundred meters from the Gebel Ramlah paleo-lake shore, the first and fourth authors discovered one of the most unique Neolithic burial complexes known in northeastern Africa and beyond. It included a cemetery for the burial of infants, which was placed next to a much larger cemetery for older children, juveniles, and adults. Both areas date to the Final Neolithic period (site E-0902). Single graves and small aggregations of graves from different Neolithic phases were also found in the vicinity. Other cemeteries and single burials were located as well nearby (Fig. 2). Together, they form an exceptional interment area that was used for millennia by Neolithic herders.

\section{New Research at Gebel Ramlah: Environment and Settlement Sequence}

Gebel Ramlah is a pronounced, rocky massif on the landscape that rises approximately $100 \mathrm{~m}$ above the surrounding desert floor (Fig. 3). To the south, a lake existed during the early and middle Holocene that would have measured some $2.5 \mathrm{~km}$ long by $0.6 \mathrm{~km}$ wide (Fig. 2). Morphology of the shore zone, modified by erosion and deflation, is diversified. Northern shores, located near the steep southern slopes of the Gebel, are morphologically uniform with clearly visible lake terraces, cut by short stream channels (wadi) draining waters from the Gebel to the lake. The more diversified landscape of the southern and western shores is dominated by large and wide river channels with 


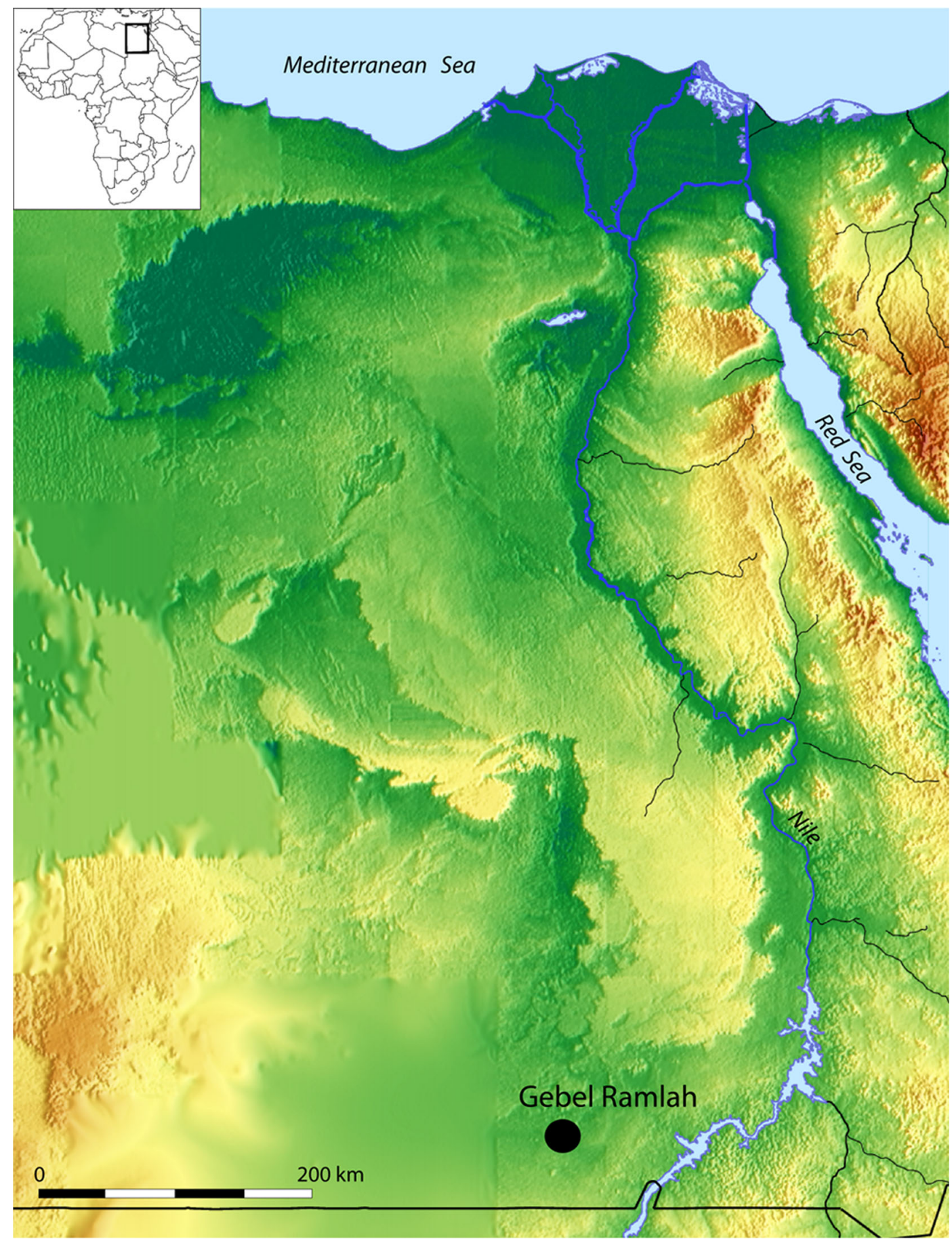

Fig. 1 Location of Gebel Ramlah site. (images in full colour online)

numerous smaller tributaries that delivered waters from a vast catchment area to the lake. Hillocks and large peninsulas between the channels and gentle slopes are typical. They are significantly more extensive in size than those on the northern shore. Lastly, the eastern edges of the lake are mostly covered by sand dunes but, where observation is possible, the banks' slopes appear to be gentle.

During the course of survey, evidence of a diverse human occupation was recorded including large, longterm settlements, small occupations, short-lived camps, 


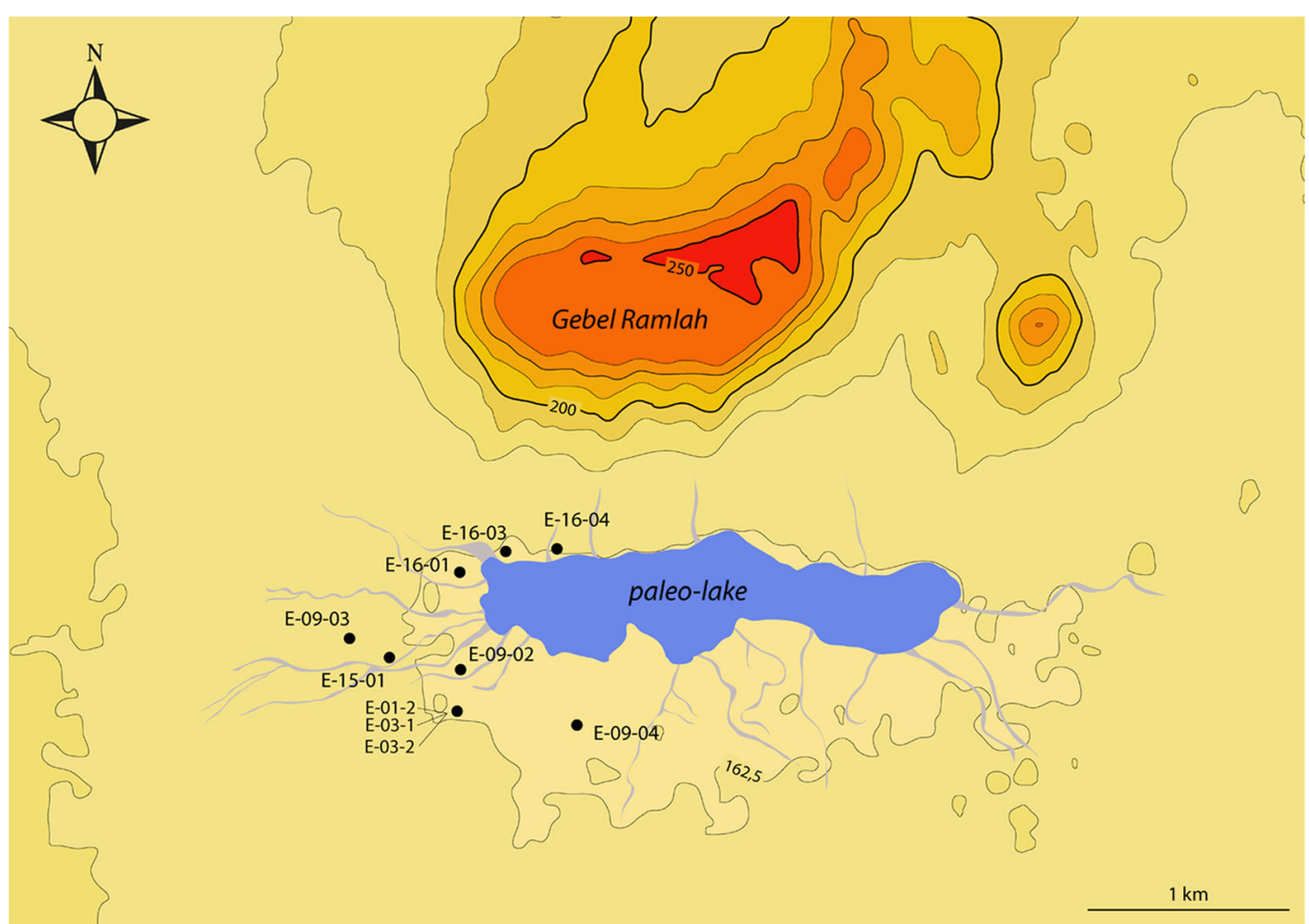

Fig. 2 Extension of Gebel Ramlah paleo-lake and location of Neolithic cemeteries (drawing: J. Kabaciński)

and traces of penetrations. In a chronological/cultural perspective, the earliest evidence of human presence dates to the Early Neolithic (El Adam and El Ghorab units) and the most intensive occupation developed during the climatic optimum of the Holocene (El Jerar unit), followed by more sparse Middle, Late, and Final Neolithic settlements (Czekaj-Zastawny et al. 2017).
The southwestern shores of the lake merit special attention. A concentration of six cemeteries, grave clusters, and single burials comprising the most unusual mortuary grounds of Neolithic pastoralists recorded in the Western Desert, were discovered and excavated. The earliest evidence of mortuary practices, in the form of single separate burials, is radiocarbon-dated to the

Fig. 3 View from the south of Gebel Ramah and surrounding desert (photo: A. CzekajZastawny)

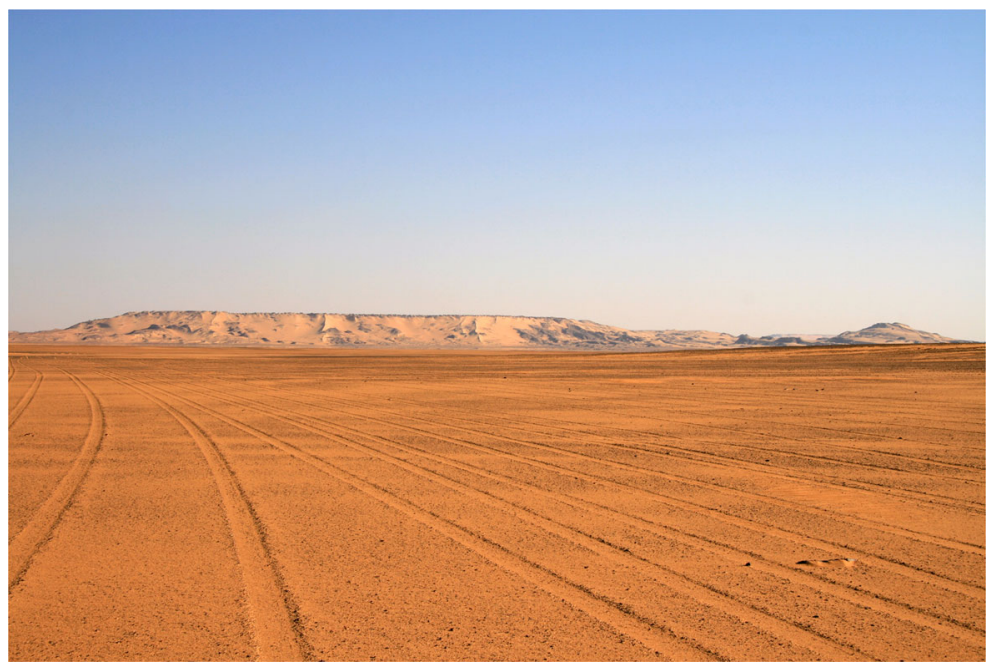


second half of the Early Neolithic (ca. 6500 BC), followed by Middle and Late Neolithic burials. Only later, at the advent of the Final Neolithic (ca. 4500 BC), were actual cemeteries were established.

\section{Cemetery of Newborns}

Perhaps the most unique Gebel Ramlah cemetery is the one primarily reserved for newborns. It is part of an ancient burial complex (site E-09-02) located on a pronounced hillock near the former lake shore (Fig. 2) that includes also a large cemetery for adults, juveniles, and older children. Radiocarbon assays indicate that the cemetery for newborns dates between ca. 4500-4300 BC.

\section{Methods}

Extreme climatic conditions of today's Sahara are destructive for human skeletal remains, especially the fragile bones of infants. It was fortunate that the site was found, because intensive wind erosion had already removed the uppermost parts of the grave pits and, in several more years, the cemetery and contents would have essentially disappeared.

During excavations, standard archaeological methods were used to record basic features, such as grave construction, stratigraphic context, position and orientation of a skeleton, presence of grave goods and pattern of distribution, additional ceremonial behaviors (e.g., presence of grave goods), spatial relation to other burials, and settlements. Most skeletons were extremely friable, fragmented, and in a poorly preserved state. This is due to post-depositional breakdown of the remains, or diagenesis, resulting from a lack of suitable mineral replacement of bone collagen, as well as exposure to direct sun and wind. However, in most graves, the state of preservation was at least adequate to permit estimation of the age at time of death. Nevertheless, such poor preservation radically narrows the analytical possibilities, based on human osteology and bio-physiochemical sciences.

The osteological analyses were conducted using standard methods in the study of infant remains in an attempt to discern not only age at death, but potentially such features as body length, a weight estimate, and in rare instances sex (Maresh 1970; Gindhart 1973; Fazekas and Kósa 1978; Ferembach et al. 1980; Scheuer et al. 1980; Weaver 1980; Brothwell 1981; Jeanty 1983; Ubelaker 1987, 1989; Walker et al. 1988; Molleson and Cox 1993; Schutkowski 1993; Buikstra and Ubelaker 1994; Scheuer and MacLaughlin-Black 1994; Holcomb and Konigsberg 1995; Sherwood et al. 2000; White and Folkens 2000; Liversidge and Molleson 2004; Irish et al. 2008; Schaefer et al. 2009; Potter et al. 2014). Other than dental crown formation (e.g., AlQahtani 2009), age and the other features are determined from skeletal element measurements, most notably long bone lengths, pelvic bone dimensions, and unfused cranial elements including the base of the skull (pars basilaris) and inner ear (pars petrosal) (e.g., Fazekas and Kósa 1978). Given such poor preservation, the latter bone, which is the densest in composition of the infant skeleton, often proved to be the only element available for study; unfortunately, even it could not be precisely measured, so ages are approximate rather than exact (i.e., in weeks pre- or post-natal) and the other features could not be ascertained.

\section{The Cemetery}

Like all other Gebel Ramlah cemeteries excavated to date, many burial pits were concentrated in a limited area, in some cases with later inhumations disturbing earlier ones. The infant cemetery measures $6 \times 8 \mathrm{~m}$, yet contained 35 burial pits with skeletal remains of 42 individuals (Fig. 4). Three individuals (burials 5, 16, and 37) were subsequently determined to belong to an older settlement horizon, so are not discussed further. The remaining 32 pits contained a total of 39 individuals. The pits are mostly oval, averaging 25 to $65 \mathrm{~cm}$ in length. Depth appears to have varied, but it is impossible to reconstruct this dimension due to extensive soil erosion. Pits were mostly dug in surface sand, sometimes reaching the underlying silt. Skeletal preservation varies from poor to fair, with remains in deflated burials on or near the surface in the poorest condition. In some cases, only bone staining was evident in the soil, whereas in others a few recognizable bones or, occasionally, a fragile, nearly complete skeleton were present.

Thirty-two individuals $(82 \%)$ are infants, i.e., perinates and neonates (in cases when the state of preservation was too poor to determine whether the skeletal remains belonged to a perinate or neonate, the remains were simply classified as 'infant'). Age determinations are based on measurements of diagnostic skeletal 


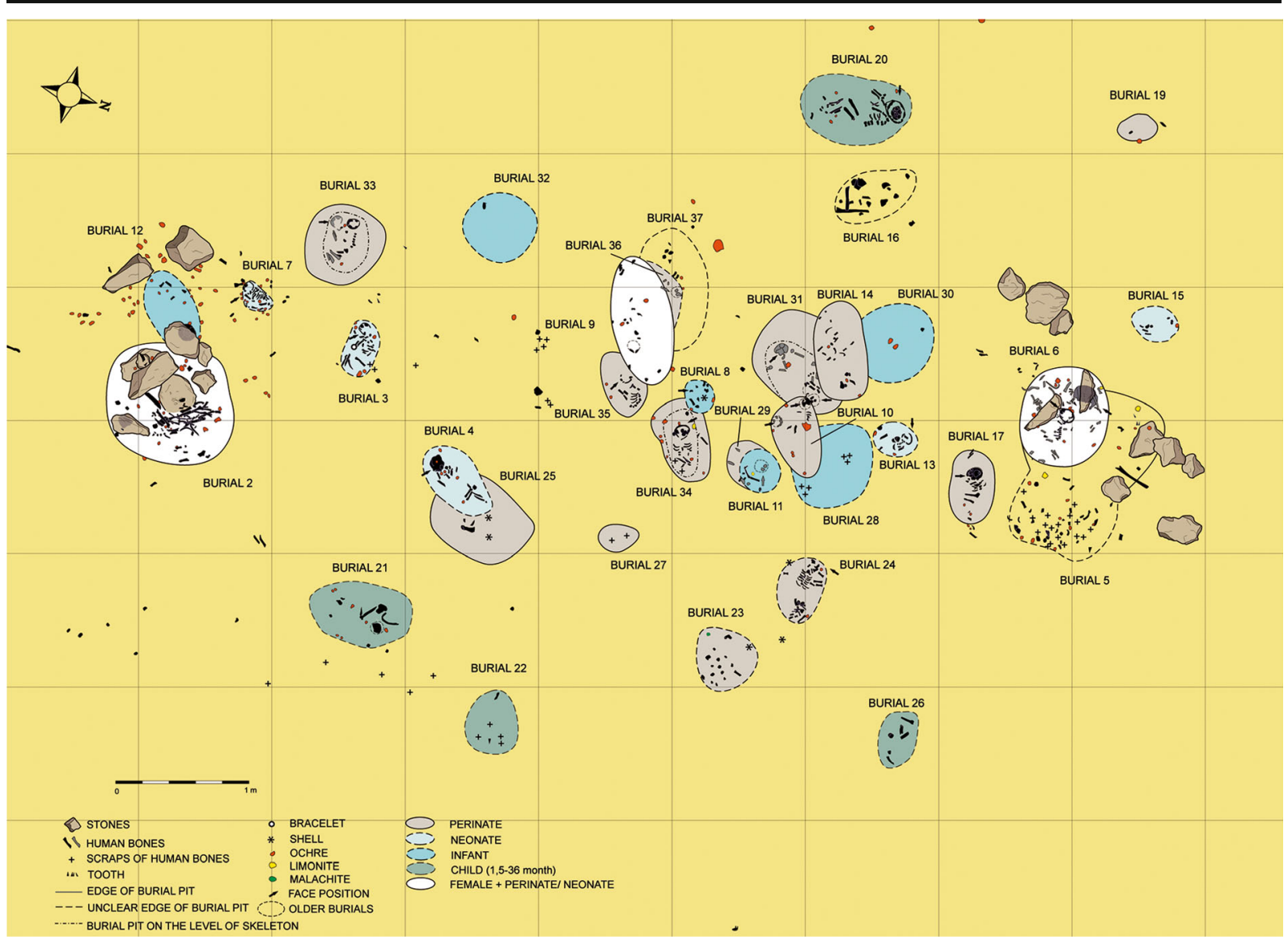

Fig. 4 Gebel Ramlah. Map of the cemetery for newborns (drawing: K. Juszczyk and J. Kabaciński)

elements (Maresh 1970; Gindhart 1973; Fazekas and Kósa 1978; Scheuer et al. 1980; Jeanty 1983; Molleson and Cox 1993; Scheuer and MacLaughlin-Black 1994; Schaefer et al. 2009), including the most dense, and hence best preserved, petrous bones, and in some instances deciduous tooth crown formation (Liversidge and Molleson 2004; AlQahtani 2009), following standard procedure (see Irish et al. 2008; Potter et al. 2014; Online Resource 1). Another four individuals were identified as young children between 1.5 and 36 months. The remaining three individuals in the cemetery were either of juvenile $(n=1)$ or adult $(n=2)$ age, i.e., $13-18$ and > 18 years of age, respectively (Ferembach et al. 1980; Bass 1995; White and Folkens 2000). The juvenile (burial 6) was roughly \pm 14 years old, and likely a female based on characteristic, though incomplete, cranial, and pelvic features (Ferembach et al. 1980; Walker et al. 1988; Buikstra and Ubelaker 1994). The other two are adults ( $>18$ years), one of which retains enough diagnostic skeletal elements to be identified as female (burial
$2)$; the other is of indeterminate sex (burial 9). Both females in burials 2 and 6 as well as the adult individual in burial 9 were interred with the remains of a perinate or neonate (Supplementary data-Table 1, and below).

Where possible to determine, all deceased were placed in a contracted position, mostly on their right side. There does not appear to have been a rule concerning compass orientation; neither W-E nor N-S directions prevail. However, if a W-E orientation was followed, the head of most individuals was toward the west and facing south; for N$\mathrm{E}$ orientation, the head was directed north and facing west. This variation does not correspond to cemetery chronology. Most burials contained one body, though seven contained two. Burials 10 and 33 held perinates of similar size, and therefore age, which could circumstantially be interpreted as twins. Unfortunately, aDNA could not be recovered from the poorly preserved remains to substantiate this possibility. In each pit, the two infants had been placed on their right sides, in close contact with each other (Fig. 5). Lastly, burial 31 contained a perinate 


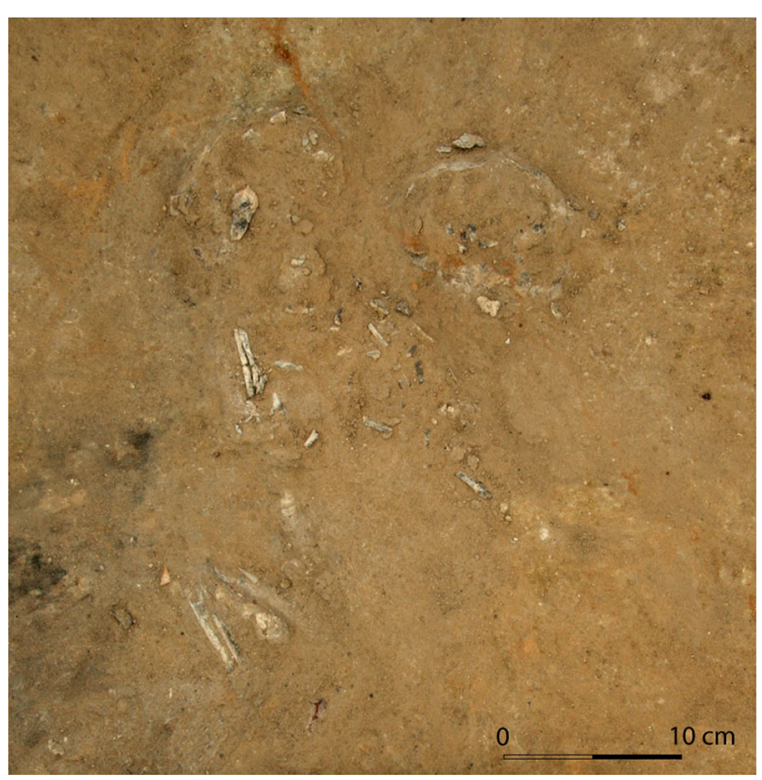

Fig. 5 Gebel Ramlah. Cemetery for newborns. Burial 33 (photo: A. Czekaj-Zastawny)

and 3-4-month-old child placed in reverse position on their right sides.

In the cases of older individuals buried with infants, body position in burial 2 is indeterminate, while the better preserved burial 6 juvenile was positioned on her left side with a neonate on her upper right thorax. It is tempting to hypothesize that these two individuals died during or shortly after childbirth and were buried with their offspring. Again, a familial relationship of this type could only be confirmed by the comparison of aDNA which, as noted, has been unsuccessful to date. Nevertheless, it may be that "mother and child" burials had a special meaning. Both were provided with stone superstructures (again see Fig. 4) and located on opposite edges of the cemetery. Perhaps, as the oldest individuals, they served to spatially delimit the cemetery on the landscape.

Beyond these two females, sex determination was impossible due to the very young age of deceased. However, some additional data may be derived from the archaeological context. Most individuals in the cemetery were placed in the burial pit on their right side. However, the female from burial 6 was on her left with a piece of limonite near the face. This combination of features repeats in three perinate burials (nos. 29, 34, and 36). Perhaps, it is an indication of sex (i.e., female).

The burials contained few grave goods, limited primarily to adornments and colorants. One unique find is a bracelet made of hippopotamus ivory found on the right

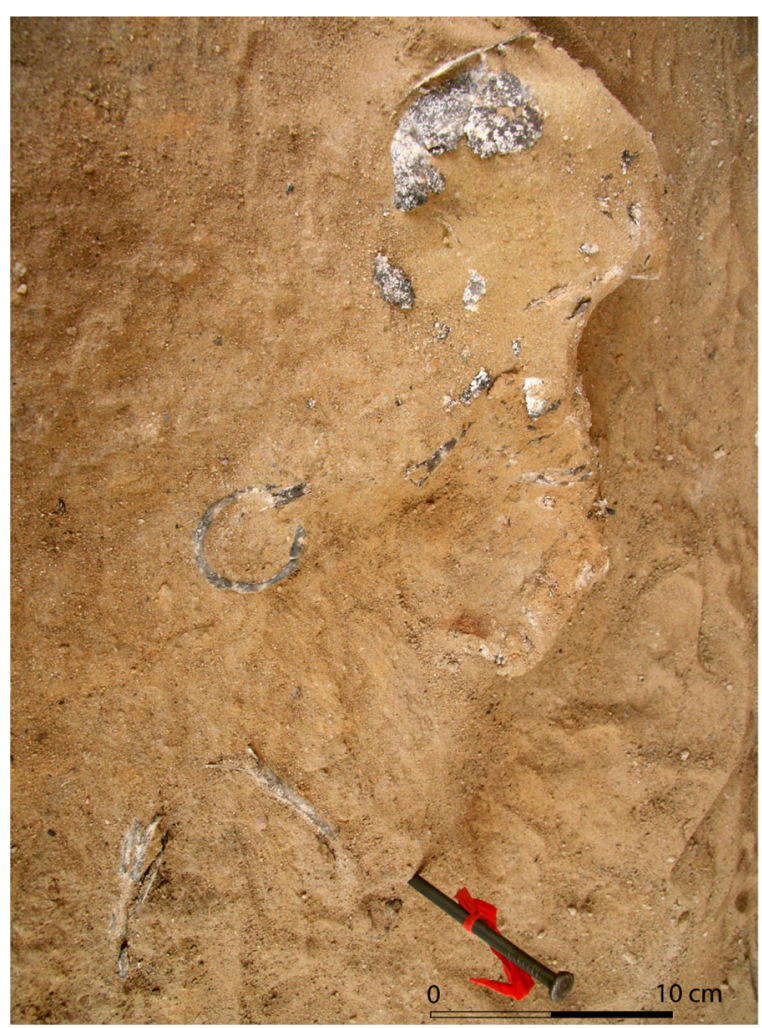

Fig. 6 Gebel Ramlah. Cemetery for newborns. Burial 3 (photo: A. Czekaj-Zastawny)

arm of a neonate in burial 3 (Fig. 6). In burial 8, a perforated shell of the Red Sea Nerita sp. snail was recorded. In another three graves (nos. 23, 24, and 25), fragments of small bivalves, most likely from the Nile, were discovered. However, the most common grave good was red ochre, present in almost each burial. Lumps of this mineral, varied in size, were present around and among the bones. In four burials, single, small pieces of limonite were recorded, in all cases near the head of deceased on left side. In burial no. 23, a fragment of malachite was present together with a bivalve.

No obvious signs of post-mortem manipulation of the human remains were recorded, with one possible exception. In the southern part of the cemetery, a concentration of burials containing completely (nos. 3, 7, and 33) or partially (no. 2) burned skeletons was recorded. Because the skeletons appear untouched (e.g., not disturbed by subsequent burial episodes), it seems that the deceased were placed within a pit dug into an active (still hot) fireplace. The temperature of each fireplace was high enough to burn soft tissue and scorch the bones. This practice was likely intentional, though we cannot ascertain the rationale. 


\section{Chronology}

Chronology of the cemetery is based on ten AMS radiocarbon analyses of skeletal remains (all the dates are calibrated with the help of OxCal Program version 4.2.3 and IntCal 2013 calibration curve), three of them made on ultrafiltered collagen (Bronk Ramsey et al. 2004), whereas the remaining seven analyses were made on structural carbonates (Lanting et al. 2001). The latter method, although recommended for dating of cremated (calcined) bones, in these specific conditions (shallow burials in very dry sands barren of calcareous formations), gave ${ }^{14} \mathrm{C}$ dates not differing from those obtained on collagen (Online Resource 2). Therefore, we consider the carbonate-based ${ }^{14} \mathrm{C}$ ages as reliable too. Calibrated dates of the analyzed samples range between ca. 4700-4300 BC (95.4\% probability; Fig. 7; Online Resource 2). However, considering the range of the oldest dates and the end of an arid phase between the Late and Final Neolithic (Schild and Wendorf 2013), one might expect that it was used for a shorter period, ca. $4600 / 4500-4350 \mathrm{BC}$, in the very beginning of the Final Neolithic Period.

Both burials with stone constructions containing remains of females with newborn infants were dated (burials 2 and 6), and they belong to the four oldest grave-age estimates for the cemetery. It seems that they delimit the extension of the cemetery. The remaining eight dates were obtained either for perinates (burials 17 , 24, 33, and 34), a neonate (burial 3), or infants (burials 20, 21 and 31); Online Resource 2.

The dated burials were found in three stratigraphic levels (1, 2, and 3); however, radiocarbon dates precluded any chronological meaning as to the pits' vertical sequence. In light of lack of stratigraphic order, we regard the dates of the 10 burials as randomly distributed over the period of the cemetery's utilization. So, this time window was modeled as a phase in the ${ }^{14} \mathrm{C}$ calibration program Oxcal 4.2.3 (Bronk Ramsey 2009; Bronk Ramsey and Lee 2013) that indicated the phase most probably begun around $4500 \mathrm{BC}$ and ended before $4300 \mathrm{BC}$ (Fig. 7).

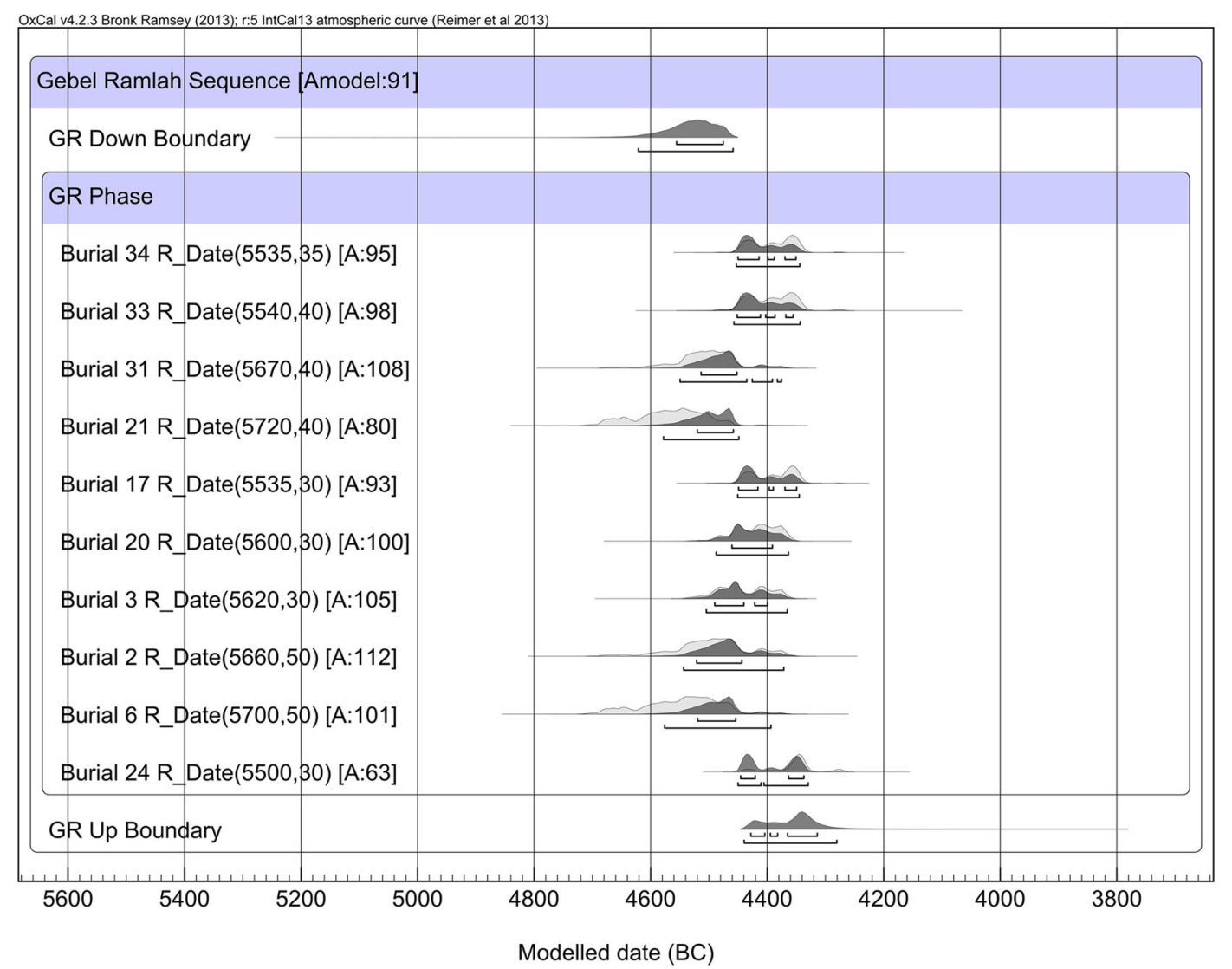

Fig. 7 Gebel Ramlah. Cemetery for newborns. Calibration of radiocarbon dates 


\section{Discussion}

Finds of skeletal remains of fetuses, perinates, and neonates are rare at prehistoric sites for a number of reasons, including the fine and fragile nature of their bones, postdepositional processes differentially affecting these remains, and likely cultural behaviors (Tocheri et al. 2005). The low number of finds stands in contrast to modern examples. Data collected by the U.N. Interagency Group for Child Mortality Estimation (http://data.worldbank.org/indicator/SH.DYN.MORT) show that in 1960, before the introduction of organized health care, the mortality rate for African countries was ca. $30 \%$. On the other hand, in the Roman world, the mortality rate at birth was around $8 \%$, reaching $30 \%$ during the first year of life (Gowland et al. 2014).

Nevertheless, such finds are known from different parts of the world since early in prehistory. Probably, the oldest evidence of intentional infant inhumation comes from Krems-Wachtberg in Austria. A burial of two neonates (possible twins) was found at an Upper Paleolithic Gravettian site dated to ca. 29,500 BC, which was located near another grave of a ca. 3-month-old infant (Einwögerer et al. 2006; Einwögerer et al. 2009). Such cases are also known from Asia. At the Lokomotiv site near Irkutsk (Lake Baikal region), a large cemetery dated to $6000-5000 \mathrm{BC}$ contained the skeleton of a 20-25-year-old woman with two perinatal skeletons, possibly twins (Lieverse et al. 2015). A similar but younger case (ca. 2100-1050 BC) is known from the Late Neolithic site An Son (southern Vietnam). In this instance, a young adult female with an unborn full-term fetus was buried (Willis and Oxenham 2011). At the Khok Phanom Di site in Thailand (ca. 2000-1500 BC), numerous perinate/neonate burials were found, including four inhumations of twins (Halcrow et al. 2008, 2012). In Oman, at the Ra's al Hamra RH5 site (ca. 3800-3300 BC), several burials of perinates were discovered. The most intriguing if these are four cases of females accompanied by perinates; one of these females was associated with twins (one still in the womb) and another had the infant placed on her chest (Coppa et al. 1985; Munoz 2008).

Examples of burials of very young children are also known from Northeast Africa, an area geographically closer to Gebel Ramlah. At the Late Neolithic cemetery R12 in northern Sudan (Dongola area; ca. 49004400 BC), five perinatal graves are known (Salvatori and Usai 2008). At Kadero, an Early Neolithic cemetery dated between 4450 and 3900 BC (Kabaciński 2011; Chłodnicki and Kabaciński 2015), 10 burials of infants were recorded (Chłodnicki et al. 2011). A typical feature of all these examples is that the inhumations were dispersed across the cemetery, which in every case covers a large area. Inhumations of infants were also found at Nubian A-Group cemeteries (ca. 3400-3000 BC). In two cases, women with a fetus were excavated (Zegretti 2012). Finally, farther to the north around the Mediterranean Sea, Greco-Roman and Ancient Egyptian examples of infant inhumations are also present, i.e., intentional burials and places of deposition or abandonment (Hopkins 1983; Smith and Kahila 1992; Tocheri et al. 2005; Becker 2007; Gowland et al. 2014).

The Neolithic infant cemetery at Gebel Ramlah is unique, with no close analogies in prehistory. Prior to its discovery, only three burials of infants in the Western Desert were known, i.e., from the Gebel Ramlah Final Neolithic family cemeteries excavated in 2001 and 2003 (Kobusiewicz et al. 2004, 2010). From North Africa, two cases of separate cemeteries for children are known. About 3020-2880 BC, 1000 years later than Gebel Ramlah, at Elkab in the Nile Valley a child cemetery was founded. It was built of three circular structures containing 41 burials. Most graves contained the remains of children, including just three neonates (Hendrickx et al. 2002). A much more recent example, dated between eighth and second century $\mathrm{BC}$, is known from Cartagina on the southern Mediterranean Sea coast. Beyond a cemetery for adults and older children, a separate burial area for perinates up to 5-6 months old was discovered (Schwartz et al. 2010).

There is minimal evidence for burial practices of pastoral societies inhabiting the Western Desert. Fewer than 10 burials are known from Gebel Nabta and El Ghorab Playa. That record has now been substantially enlarged by the Gebel Ramlah discoveries, mostly for the Late and especially Final Neolithic. Two burials from Nabta Playa are possibly linked with the Early Neolithic (El Jerar phase), unfortunately dated by a settlement context only (Irish 2001; Wendorf and Schild 2001a, b). The only directly dated burial from that period was found in Gebel Ramlah (site E-15-01, burial 1).

Two burials from the Middle Neolithic come from Gebel Ramlah and are dated to ca. 6000-5700 BC. Evidence for the Late Neolithic is growing substantially, as several inhumations from that time are now known. Again, most of these burials from the Nabta-Kiseiba area are dated by archaeological context only 
(Wendorf and Schild 1980; Irish 2001; Kobusiewicz et al. 2004); however, six Late Neolithic inhumations from Gebel Ramlah are directly dated between ca. 5250 and $4650 \mathrm{BC}$. A number of common features characterize all these inhumations: (i) contracted body position; (ii) an almost complete lack of grave goods, and (iii) a dispersed location on the periphery or outside of settlements. A fundamental change in burial behavior appeared during the Final Neolithic, as manifested by a diverse record from Gebel Ramlah. From ca. 4500 BC onward, the deceased were buried in cemeteries.

The infant cemetery served, first of all, children who died near the time of their birth, though four older children (1.5 to 36 months) were also present. It appears that an age of 3 years was the cutoff point for inclusion of the deceased, because all older children were buried at the nearby cemetery for adults, containing no fewer than 60 inhumations of older children (from 3.5 years) and adults. The only exceptions are burials of the two older females with infants. Their chronology, i.e., potentially the first burials in the cemetery, location along the edges of the cemetery, and presence of stone superstructures may suggest a kind of symbolic role that they played, as protectors of the deceased infants.

During a brief period, ca. $4500-4300$ BC at Gebel Ramlah, at least six separate cemeteries were in use covering an area of ca. $0.5 \mathrm{~km}^{2}$ (Kobusiewicz et al. 2004, 2010; Czekaj-Zastawny and Kabaciński 2015). The infant cemetery and abovementioned cemetery for adults (site E-09-02) should be considered as one burial complex of the same pastoral population. The same date of the deceased at both cemeteries and location on the same hillock suggests that they reflect the mortality structure of one population.

Roughly $200 \mathrm{~m}$ to the south, a complex of another three cemeteries is located (sites E-01-2, E-03-1 and E03-2; Fig. 2), from the same period, though representing a different mortuary tradition. In total, 68 deceased were buried there reflecting the full age spectrum of the population. They are interpreted to represent large family cemeteries (Kobusiewicz et al. 2004). All of these burials contained numerous grave goods, including many made of exotic materials. Each cemetery includes primary and secondary burials (usually multiple), potentially indicating a high degree of group mobility.

In contrast, only primary burials were found at the infant cemetery. This indicates that they were born in the Gebel Ramlah area. It is also indicative of at least a semi-permanent occupation there. On the other hand, the presence of exotic goods (e.g., a bracelet of hippopotamus ivory, shells from the Red Sea, and Nile mollusks and bivalves) may suggest part of population was occasionally mobile. It is possible to imagine that women were staying with children at the settlement while men were crossing savannas to graze animals or hunt, as takes place with the Sudanese Nuer in modern times (Gifford-Gonzalez 2005). The local environment at Gebel Ramlah, with a temporary lake during the rainy season, surrounded by savannah with tamarisk bushes and sparse acacia trees (Lityńska-Zając 2010), enabled a more or less permanent stay for ca. 200 years.

The area around Gebel Ramlah was settled since the beginning of the Early Neolithic, and the density of settlement reached its maximum during the El Jerar phase (climatic optimum of the Holocene). Traces from the Middle, Late, and Final Neolithic are less intensive and random. In fact, for the Final Neolithic, we have more information on mortuary behavior than for the settlement pattern and subsistence. Between 4500 and 4300 BC, south-western fringes of the Gebel Ramlah lake served as an extended burial ground for different populations. Different ancestry and relationships of these populations can be followed on the basis of archaeological and, partially, bioarchaeological arguments. Some groups (using cemeteries E-01-2, E-03-1, E-032, and E-09-4) show some affiliation with sub-Saharan Africans, readable in the pottery assemblage and other grave goods, as well as some morphological features (Irish 2010; Kobusiewicz and Kabaciński 2010; Czekaj-Zastawny and Kabaciński 2015). These people were certainly mobile, perhaps spending only a few months per year at Gebel Ramlah. The E-09-02 cemeteries for neonates and adults belonged to another, more sedentary group with limited mobility; however, we cannot trace their origins based on the available record. An almost complete lack of grave goods does not allow comparative analyses. On the other hand, peculiar characters of the skeletal remains at these cemeteries - numerous neonatal/perinatal individuals and poorly preserved subadults/adults - do not allow reliable studies based on craniometric or dental data. But, qualitatively, there are no obvious differences among all populations from Gebel Ramlah at the beginning of the Final Neolithic. Thus, the two groups, culturally different, were likely not much different biologically, possibly deriving from the same region of Africa.

Ethnological and archaeological research provides examples of various treatments of dead infants. From 
prehistory, the evidence is scarce, as we record only those cases when infants were treated with care and were buried. From the better known Roman world, we have examples of different, impersonal treatment of the deceased related to emotional indifference to infants, in the form of abandonment or infanticide (Gowland et al. 2014). Ethnographic data offer support by showing how radically different children are treated in various African societies (Gottlieb 2004a, b; Pawlik 2004; Kabaciński et al. 2018). Mortuary practices depend on social position and the status of children and often yield extremely different forms (Han et al. 2017). Among the Anyi (Côte d'Ivoire), if the birth was at home, the deceased infant is discarded between kitchen middens (Eschliman 1985). Conversely, in the Beng world, children have an important position in society, though they do not organize funerals for infants because they are considered as persons not completely ready to return to the world of the living (Gottlieb 2004a, b; Bielo 2015).

From the above perspective, the infant cemetery at Gebel Ramlah seems to be a special case, largely absent in prehistory and rare in modern times. An unusual attitude toward infants suggests that children, from their very beginning, were important members of the pastoral society inhabiting the Western Desert at the end of the Neolithic.

Acknowledgments The research in Gebel Ramlah was conducted under the permission granted to the Combined Prehistoric Expedition by the Egyptian Ministry of Antiquities. The authors express warm thanks to Egyptian Authorities for their assistance. Maarten Horn kindly identified the raw material from which the bracelet in burial 3 was made.

Funding Information This study was funded by the National Science Centre, Poland (grant No. NCN 2012/05/B/HS3/03928) and the Combined Prehistoric Expedition Foundation. The authors thank both institutions for support.

\section{Compliance with Ethical Standards}

Conflict of Interest The authors declare that they have no conflict of interest.

Open Access This article is distributed under the terms of the Creative Commons Attribution 4.0 International License (http:// creativecommons.org/licenses/by/4.0/), which permits unrestricted use, distribution, and reproduction in any medium, provided you give appropriate credit to the original author(s) and the source, provide a link to the Creative Commons license, and indicate if changes were made.

\section{References}

Alley, R. B., Meese, D. A., Shyman, C. A., Gow, A. J., Taylor, K. C., Grootes, P. M., et al. (1993). Abrupt increase in Greenland snow accumulation at the end of Younger Dryas event. Nature, 362, 527-529.

AlQahtani, S. J. (2009). Atlas of human tooth development and eruption. Queen Mary and Westfield College. www.atlas. dentistry.qmul.ac.uk.

Applegate, A., \& Zedeño, N. (2001). Site E-92-8: A late prehistoric C-group component at Nabta Playa. In F. Wendorf, R. Schild, \& Associates (Eds.), Holocene settlement of the Egyptian Sahara. Vol. 1. The archaeology of Nabta Playa (pp. 529-533). New York: Kluwer Academic/Plenum Publishers.

Bass, W. M. (1995). Human osteology: A laboratory and field manual. Columbia: Missouri Archaeological Society.

Becker, M. J. (2007). Childhood among the Etruscans: Mortuary programs at Tarquinia as indicators of the transition to adult status. http://digitalcommons.wcupa.edu/anthrosoc facpub/16.

Bielo, J. S. (2015). Anthropology of religion: The basics. New York: Routledge.

Bronk Ramsey, C. (2009). Bayesian analysis of radiocarbon dates. Radiocarbon, 51, 337-360.

Bronk Ramsey, C. \& Lee, S. (2013). Recent and planned developments of the program OxCal. I, pp. 720-730.

Bronk Ramsey, C., Higham, T. F. G., Bowles, A., \& Hedges, R. (2004). Improvements to the pretreatment of bone at Oxford. Radiocarbon, 46, 155-163.

Brothwell, D. R. (1981). Digging up bones. Ithaca: Cornell University Press.

Buikstra, J. E., \& Ubelaker, D. H. (1994). Standards for data collection from human skeletal remains (Vol. 44). Fayetteville: Arkansas Archaeological Survey Research Series.

Chłodnicki, M., \& Kabaciński, J. (2015). Radiocarbon dates from Kadero revised. In J. Kabaciński, M. Chłodnicki, \& M. Kobusiewicz (Eds.), Hunter-gatherers and early food producing societies in northeastern Africa (Studies in African Archaeology 14) (pp. 195-217). Poznań: Poznań Archaeological Museum.

Chłodnicki, M., Kobusiewicz, M., \& Kroeper, K. (2011). Kadero. Poznań: Poznań Archaeological Museum.

Coppa, A., Macchiarelli, R., Salvatori, S., \& Santini, G. (1985). The prehistoric graveyard of Ra's al-Hamra 5 (RH-5). A short preliminary report on the 1981-1983 excavations. The Journal of Oman Studies, 8(1), 97-102.

Czekaj-Zastawny, A., \& Kabaciński, J. (2015). New Final Neolithic cemetery E-09-4, Gebel Ramlah Playa, Western Desert of Egypt. In J. Kabaciński, M. Chłodnicki, \& M. Kobusiewicz (Eds.), Hunter-gatherers and early food producing societies in northeastern Africa (Studies in African Archaeology 14) (pp. 375-384). Poznań: Poznań Archaeological Museum.

Czekaj-Zastawny, A., Irish, J., Kabaciński, J., \& Mugaj, J. (2017). The Neolithic settlements by a paleo-lake of Gebel Ramlah, Western Desert of Egypt. In J. Kabaciński, M. Chłodnicki, \& M. Kobusiewicz (Eds.), Hunter-gatherers and early food producing societies in northeastern Africa (Studies in 
African Archaeology 14). Poznań: Poznań Archaeological Museum.

Einwögerer, H. F., Friesinger, H., Handel, M., NeugebauerMaresch, C., Simon, U., \& Teschler-Nicola, M. (2006). Upper Palaeolithic infant burials. Nature, 444, 285.

Einwögerer, T., Händel, M., Neugebauer-Maresch, C., Simon, U., Steier, P., Teschler-Nicola, M., et al. (2009). 14C dating of the Upper Paleolithic site at Krems-Wachtberg, Austria. Radiocarbon, 51(2), 847-855.

Eschliman, J. P. (1985). Les Agni devant la mort (Côte d'Ivoire). Paris: Karthala.

Fazekas, I., \& Kósa, F. (1978). Forensic fetal osteology. Budapest: Akadémiai Kiadó.

Ferembach, D., Schwidetzky, I., \& Stoukal, M. (1980). Recommendations for age and sex diagnoses of skeletons. Journal of Human Evolution, 9, 517-549.

Gifford-Gonzalez, D. (2005). Pastoralism and its consequences. In A. B. Stahl (Ed.), African archaeology. A critical introduction (pp. 187-224). Malden: Blackwell Publishing.

Gindhart, P. (1973). Growth standards for the tibia and radius in children aged one month through eighteen years. American Journal of Physical Anthropology, 39, 41-48.

Gottlieb, A. (2004a). Babies as ancestors, babies as spirits. The culture of infancy in West Africa. Expedition: The Magazine of the University of Pennsylvania, 46(3), 13-21.

Gottlieb, A. (2004b). The afterlife is where we come from: The culture of infancy in West Africa. Chicago: University of Chicago Press.

Gowland, R. L., Chamberlain, A., \& Redfern, R. C. (2014). On the brink of being: Re-evaluating infanticide and infant burial in Roman Britain. Journal of Roman Archaeology Supplementary Series, 96, 69-88.

Halcrow, S. E., Tayles, N., \& Livingstone, V. (2008). Infant death in late prehistoric Southeast Asia. Asian Perspectives, 47(2), 371-404

Halcrow, S. E., Tayles, N., Inglis, R., \& Higham, C. (2012). Newborn twins from prehistoric mainland Southeast Asia: Birth, death and personhood. Antiquity, 86, 838-852.

Han, S., Betsinger, T. K., \& Scott, A. B. (Eds.). (2017). Anthropology of the fetus. New York: Berghahn Books.

Hendrickx, S., Huyge, D., \& Warmenbol, E. (2002). Unc imetièprea rticuli del ad euxièmdey nastàie Elkab. ArchèoNil, 12, 47-54.

Holcomb, S., \& Konigsberg, L. (1995). Statistical study of sexual dimorphism in the human fetal sciatic notch. American Journal of Physical Anthropology, 97, 113-125.

Hopkins, K. (1983). Death and renewal. Cambridge: Cambridge University Press.

Irish, J. D. (2001). Human skeletal remains from three Nabta Playa sites. In F. Wendorf, R. Schild, \& Associates (Eds.), Holocene settlement of the Egyptian Sahara. Vol. 1. The archaeology of Nabta Playa (pp. 521-528). New York: Kluwer Academic/Plenum Publishers.

Irish, J. D. (2010). The human skeletal remains from Gebel Ramlah: A physical anthropological assessment. In M. Kobusiewicz et al. (Eds.), Gebel Ramlah: Final Neolithic cemeteries from the Western Desert of Egypt (pp. 189-224). Poznań: Institute of Archeology and Ethnology.

Irish, J. D., Bratlund, B., Schild, R., Kolstrup, E., Królik, H., Manka, D., \& Boro, T. (2008). A late Magdalenian perinatal human skeleton from Wilcyzce, Poland. Journal of Human Evolution, 55, 736-740.

Jeanty, P. (1983). Fetal limb biometry. Radiology, 147, 601-602.

Kabaciński, J. (2011). Comments on radiocarbon dates. In M. Chłodnicki, M. Kobusiewicz, \& K. Kroeper (Eds.), Kadero (pp. 417-420). Poznań: Poznań Archaeological Museum.

Kabaciński, J., Czekaj-Zastawny, A., \& Irish, J. D. (2018). The Neolithic infant cemetery at Gebel Ramlah, in Egypt's Western Desert. In S. Han, T. K. Betsinger, \& A. B. Scott (Eds.), The anthropology of the fetus. Biology, culture, and society (pp. 132-145). New York: Berghahn Books.

Kobusiewicz, M., \& Kabaciński, J. (2010). Cemeteries. In M. Kobusiewicz et al. (Eds.), Gebel Ramlah: Final Neolithic cemeteries from the Western Desert of Egypt (pp. 7-115). Poznań: Institute of Archeology and Ethnology.

Kobusiewicz, M., Kabaciński, J., Schild, R., Irish, J. D., \& Wendorf, F. (2004). Discovery of the first Neolithic cemetery in Egypt's Western Desert. Antiquity, 78(301), 566-579.

Kobusiewicz, M., Kabaciński, J., Schild, R., Irish, J. D., Gatto, M., \& Wendorf, F. (2010). Gebel Ramlah. Final Neolithic cemeteries from the Western Desert of Egypt. Poznań: Institute of Archeology and Ethnology.

Kuper, R., \& Kropelin, S. (2006). Climate-controlled Holocene occupation in the Sahara: Motor of Africa's evolution. Science, 313, 803-807.

Lanting, J. N., Aerts-Bijma, A. T., \& Van der Plicht, J. (2001). Dating of cremated bones. Radiocarbon, 43, 249-254.

Lieverse, A. R., Bazaliiskii, V. I., \& Weber, A. W. (2015). Death by twins: A remarkable case of dystocic childbirth in Early Neolithic Siberia. Antiquity, 89, 23-38.

Lityńska-Zając, M. (2010). Archaeobotanical investigations on sites at Gebel Ramlah. In M. Kobusiewicz et al. (Eds.), Gebel Ramlah: Final Neolithic cemeteries from the Western Desert of Egypt (pp. 239-246). Poznań: Institute of Archeology and Ethnology.

Liversidge, H. M., \& Molleson, T. (2004). Variation in crown and root formation and eruption of human deciduous teeth. American Journal of Physical Anthropology, 123, 172-180.

Lowe, J. J., Rasmussen, S. O., Björck, S., Hoek, W. Z., Steffensen, J. P., Walker, M. J. C., et al. (2008). Synchronisation of palaeoenvironmental events in the North Atlantic region during the Last Termination: A revised protocol recommended by the INTIMATE group. Quaternary Science Reviews, 27, 6-17.

Maresh, M. M. (1970). Measurements from roentgenograms. In R. W. McCammon (Ed.), Human growth and development (pp. 157-200). Springfield: C. C. Thomas.

Molleson, T., \& Cox, M. (1993). The Spitalfields Project. Vol. 2: The anthropology (CBA Research Report 86). London: Council for British Archaeology.

Munoz, O. (2008). The IV ${ }^{\text {th }}$ millennium graveyard of RH-5 heritage site (Ra's al-Hamra, Sultanate of Oman): New excavations. Death, burial and the transition to the afterlife in Arabia and adjacent regions. London, The British Museum, 27-29 November 2008. Poster.

Pawlik, J. J. (2004). Śmierć dziecka w Afryce. In W. Dzieduszycki \& J. Wrzesiński (Eds.), Dusza maluczka a strata ogromna (Funeralia Lednickie 6) (pp. 35-75). Poznań: SNAP.

Potter, B. P., Irish, J. D., Reuther, J. D., \& McKinney, H. (2014). New insights into Eastern Beringian mortuary behavior: A terminal Pleistocene double infant burial at Upward Sun 
River. Proceedings of the National Academy of Sciences. https://doi.org/10.1073/pnas.1413131111.

Salvatori, S., \& Usai, D. (2008). A Neolithic cemetery in the Northern Dongola Reach. Excavations at site R12 (Sudan Archaeological Research Society 16, BAR International Series 1814). Oxford: Archaeopress.

Schaefer, M., Black, S., \& Scheuer, L. (2009). Juvenile osteology: A laboratory and field manual. New York: Elsevier, Inc..

Scheuer, J. L., \& MacLaughlin-Black, S. (1994). Age estimation from the pars basilaris of the fetal and juvenile occipital bone. International Journal of Osteoarchaeology, 4, 377-380.

Scheuer, J. L., Musgrave, J. H., \& Evans, S. P. (1980). The estimation of late fetal and perinatal age from limb bone length by linear and logarithmic regression. Annals of Human Biology, 3, 257-265.

Schild, R., \& Wendorf, F. (2002). Forty years of combined prehistoric expedition. Archaeologia Polona, 40, 2-22.

Schild, R., \& Wendorf, F. (2013). Early and Middle Holocene paleoclimates in the South Western Desert of Egypt - the world before unification. Studia Quaternaria. https://doi. org/10.2478/squa-2013-0013.

Schutkowski, H. (1993). Sex determination of infant and juvenile skeletons: I. Morphognostic features. American Journal of Physical Anthropology, 90, 199-205.

Schwartz, J. H., Houghton, F., Macchiarelli, R., \& Bondioli, L. (2010). Skeletal remains from Punic Carthage do not support systematic sacrifice of infants. PLoS One. https://doi. org/10.1371/journal.pone.0009177.

Sherwood, R. J., Meindl, R. S., Robinson, H. B., \& May, R. L. (2000). Fetal age: Methods of estimation and effects of pathology. American Journal of Physical Anthropology, 113, 305-315.

Smith, P., \& Kahila, G. (1992). Identification of infanticide in archaeological sites: A case study from the Late RomanEarly Byzantine periods at Ashkelon, Israel. Journal of Archaeological Science, 19, 667-675.

Tocheri, M. W., Dupras, T. L., Sheldrik, P., \& Molto, J. E. (2005). Roman period fetal skeletons from the East Cemetery (Kellis 2) of Kellis, Egypt. International Journal of Osteoarchaeology, $15,326-341$.
Ubelaker, D. H. (1987). Estimating age at death from immature human skeletons: An overview. Journal of Forensic Sciences, 32, 1254-1263.

Ubelaker, D. H. (1989). Human skeletal remains: Excavation, analysis, interpretation (2nd ed.). Washington: Taraxacum.

Walker, P. L., Johnson, J., \& Lambert, P. (1988). Age and sex biases in the preservation of human skeletal remains. American Journal of Physical Anthropology, 76, 183-188.

Weaver, D. (1980). Sex differences in the ilia of a known sex and age sample of fetal and infant skeletons. American Journal of Physical Anthropology, 52, 191-195.

Wendorf, F. (1968). The prehistory of Nubia. Dallas: The Southern Methodist University Printing Department.

Wendorf, F., \& Schild, R. (1980). Loaves and fishes: The prehistory of Wadi Kubbaniya. Dallas: Southern Methodist University Press.

Wendorf, F., \& Schild, R. (2001a). Conclusions. In F. Wendorf, R. Schild, \& Associates (Eds.), Holocene settlement of the Egyptian Sahara. Vol. 1. The archaeology of Nabta Playa (pp. 648-675). New York: Kluwer Academic/Plenum Publishers.

Wendorf, F., \& Schild, R. (2001b). Site E-77-1 and E-94-3: Two Neolithic sites Near Gebel Nabta. In F. Wendorf, R. Schild, \& Associates (Eds.), Holocene settlement of the Egyptian Sahara. Vol. 1. The archaeology of Nabta Playa (pp. 427462). New York: Kluwer Academic/Plenum Publishers.

Wendorf, F., Schild, R., \& Struever, S. (1976). Prehistory of the Nile Valley. New York: Academic Press.

White, T., \& Folkens, P. (2000). Human osteology (2nd ed.). San Diego: Academic Press.

Willis, A., \& Oxenham, M. F. (2011). A case of maternal and perinatal death in Neolithic southern Vietnam, c. 21001050 BCE. International Journal of Osteoarchaeology. https://doi.org/10.1002/oa.1296.

Zegretti, C. (2012). Child burials of the Nubian A-Group. In J. Kabaciński, M. Chłodnicki, \& M. Kobusiewicz (Eds.), Prehistory of northeastern Africa: New ideas and discoveries (Studies in African Archaeology 11) (pp. 141-152). Poznań: Poznań Archaeological Museum, IAE PAN. 